Review

\title{
Selective hydrogenolysis of glycerol to 1,3-propanediol over Pt-W based catalysts
}

\author{
Jia Wang a,, , Man Yang b,d,, , Aiqin Wang b,c,* \\ a College of Forestry, Northwest A\&F University, Yangling 712100, Shaanxi, China \\ b CAS Key Laboratory of Science and Technology on Applied Catalysis, Dalian Institute of Chemical Physics, Chinese Academy of Sciences, Dalian 116023, \\ Liaoning, China \\ c State Key Laboratory of Catalysis, Dalian Institute of Chemical Physics, Chinese Academy of Sciences, Dalian 116023, Liaoning, China \\ d University of Chinese Academy of Sciences, Beijing 100049, China
}

\section{A R T I C L E I N F O}

\section{Article history:}

Received 21 February 2020

Accepted 16 March 2020

Published 5 September 2020

\section{Keywords:}

Glycerol

Hydrogenolysis

1,3-propanediol

Pt-W based catalysts

\begin{abstract}
A B S T R A C T
The selective hydrogenolysis of glycerol to 1,3-propanediol (1,3-PDO) is an attractive reaction due to the high demand for valorization of huge excess amounts of glycerol supply as well as the important application of 1,3-PDO in polyester industry. Nevertheless, the formation of 1,3-PDO is thermodynamically less favorable than 1,2-PDO, which necessitates the development of efficient catalysts to manipulate the reaction kinetics towards the 1,3-PDO formation. Among others, Pt-W based catalysts have shown promising activities and selectivities of 1,3-PDO although the reaction mechanism is not well addressed at the molecular level. In this short review, we have compared the performances of different Pt-W based catalysts and discussed the key factors influencing the activity and selectivity. Three possible reaction mechanisms have been discussed in terms of the synergy between $\mathrm{Pt}$ and $\mathrm{WO}_{x}$ and the origin of acid sites. Finally, the long-term stability of the Pt-W catalysts has been discussed. We hope this review will provide useful information for the development of more efficient catalysts for this important reaction.
\end{abstract}

(C) 2020, Dalian Institute of Chemical Physics, Chinese Academy of Sciences. Published by Elsevier B.V. All rights reserved.

\section{Introduction}

Glycerol is a typical polyol compound produced from biomass including fat, seed oil and even lignocellulose. In particular, with the fast development of biodiesel in the past decade, a huge amount of glycerol has been produced as the byproduct in the manufacture of biodiesel via transesterification (one tonne of glycerol is generated in producing per 10 ton of biodiesel) $[1,2]$. The low cost and excess supply of glycerol calls for its valorization in order to improve the economics of the biodiesel industry. Among various possible transformations, the selective hydrogenolysis of glycerol to 1,3-propanediol (1,3-PDO) has attracted a great deal of attention. 1,3-PDO is an important monomer for the production of polypropylene terephthalate (PTT), a high quality polyester combining the advantages of nylon and terylene [3]. Currently, 1,3-PDO is mainly produced by fermentation of glycerol or glucose. Nevertheless, this bio-transformation route suffers from the low production efficiency (low substrate concentration, slow reaction rate, etc.) and the high separation cost [4], which limits the large-scale

\footnotetext{
* Corresponding author. Tel: +86-411-84379348; Fax: +86-411-84685940; E-mail: aqwang@dicp.ac.cn

+ These authors contributed equally to this work.

This work was supported by the National Natural Science Foundation of China (21706215, 21690084, 21673228), Natural Science Basic Project of Shaanxi Province (2018JQ2034), and the Fundamental Research Funds for the Central Universities (Z109021701).

DOI: 10.1016/S1872-2067(20)63586-0 | http://www.sciencedirect.com/science/journal/18722067 | Chin. J. Catal., Vol. 41, No. 9, September 2020
} 
production of 1,3-PDO. Compared with the fermentation process, chemical transformation of glycerol to 1,3-PDO via hydrogenolysis possesses inherent advantages of high glycerol concentration in the feedstock, continual operation and good scalability. The key to the hydrogenolysis of glycerol to 1,3-PDO is the development of highly active and selective catalysts.

The hydrogenolysis of glycerol involves a complex reaction network including a series of competitive and consecutive reactions. As shown in Fig. 1 [5], the hydrogenolysis of primary and secondary $\mathrm{C}-\mathrm{O}$ bonds of glycerol can lead to the production of 1,2-PDO and 1,3-PDO, respectively. Further hydrogenolysis of both diols can result in the formation of C3-alcohols such as 1-propanol (1-PO), 2-propanol (2-PO). The complete hydrogenolysis of all the three $\mathrm{C}-\mathrm{O}$ bonds leads to the formation of propane, however, usually at higher temperatures. In parallel with the $\mathrm{C}-\mathrm{O}$ cleavage, $\mathrm{C}-\mathrm{C}$ bond cleavage can also take place if the reaction is conducted at relatively harsh conditions (e.g., lower hydrogen pressure and higher temperature), which lead to the production of ethylene glycol (EG), ethanol, methanol, ethane and methane. In order to direct the reaction towards the formation of 1,3-PDO, both the catalyst and reaction conditions need to be optimized such that all the other side reactions can be limited to the least extent. Based on theoretical studies [6], the dehydration activation energies of neutral glycerol for primary and secondary - $\mathrm{OH}$ groups are very close (70.9 vs. 73.2 $\mathrm{kcal} / \mathrm{mol})$, and their proton affinities are almost identical ( $195 \mathrm{kcal} / \mathrm{mol}$ ). Moreover, the steric hindrance for cleaving the secondary $\mathrm{C}-\mathrm{O}$ bond is more than for the primary one. These unfavorable thermodynamic factors raise significant challenges for the selective formation of 1,3-PDO. Therefore, an effective catalyst should be developed so that the formation of 1,3-PDO is kinetically favorable.

It has been accepted that the hydrogenolysis of $\mathrm{C}-\mathrm{O}$ bonds usually requires bifunctional catalysts composed of a transition metal (for hydrogenation) and an acidic promoter/or support. However, it is more or less surprising that most of these metal-acid pairs unfortunately lead to the selective formation of 1,2-PDO [7,8]. In fact, there have been only two typical catalysts that are effective for the hydrogenative transformation of glycerol to 1,3-PDO. One is Ir-Re based catalysts which were first developed by Tomishige and coworkers [9-14]. Among them, the representative $\mathrm{Ir}-\mathrm{ReO}_{x} / \mathrm{SiO}_{2}$ catalyst was the most active and selective one, with 1,3-PDO yield of $38 \%$ at $81 \%$ glycerol conversion at the reaction condition of $120{ }^{\circ} \mathrm{C}$ [9]. The structure and reaction mechanism of this catalyst has been exten-

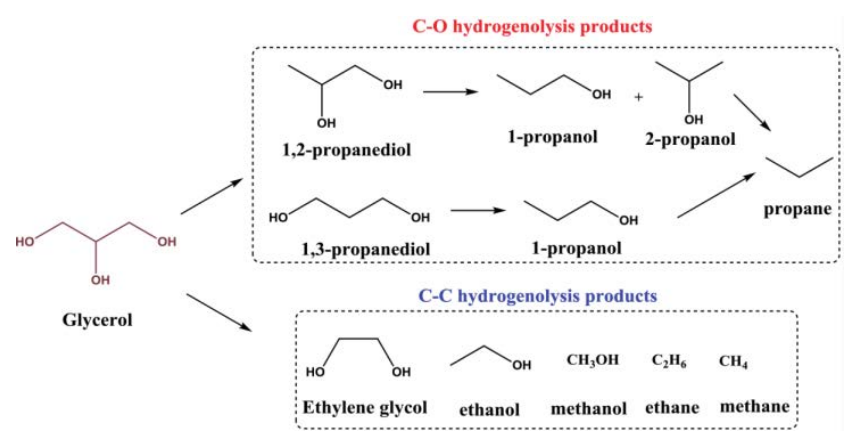

Fig. 1. Products obtained from glycerol hydrogenolysis [5]. sively studied [10-14] and summarized in an excellent review by Tomishige et al. [15] Briefly, the $\mathrm{ReO}_{x}$ is able to adsorb the primary - $\mathrm{OH}$ group of the glycerol molecule, and then the hydride formed by dissociation of $\mathrm{H}_{2}$ at the Ir sites attacks the secondary $-\mathrm{OH}$ group, followed by dehydration and hydrogenation to form 1,3-PDO. The intimate synergy between Ir and $\mathrm{ReO}_{x}$ is supposed to be responsible for the high selectivity of 1,3-PDO. Besides the Ir-Re based catalysts, the other type of effective catalysts is Pt-W based catalysts [16-18]. Compared to the Ir-Re based catalysts, the Pt-W based catalysts appear more attractive for practical applications, probably due to the low-price of $\mathrm{W}$, being active without the addition of liquid acid (e.g., $\mathrm{H}_{2} \mathrm{SO}_{4}$ ), as well as the tunability by the use of a variety of supports. Table 1 compares some typical features of Ir-Re and $\mathrm{Pt}-\mathrm{W}$ based catalysts. One can clearly see that their structures are quite different; Ir-Re is featured with $3 \mathrm{D} \mathrm{ReO}_{x}$ clusters decorated on the surface of Ir NPs, while the Pt-W is typically in the form of Pt NPs on the 2D $\mathrm{WO}_{x}$ sub-monolayers. Moreover, the Ir-Re catalysts can be highly active at a lower temperature than the Pt-W catalysts (120 vs. $\left.160-180^{\circ} \mathrm{C}\right)$. More in-depth comparative study of Pt-W and Ir-Re based catalyst is believed beneficial to the development of improved catalysts.

As far as we know, there is no review on the Pt-W based catalysts for glycerol hydrogenation. In this review, we summarize the various supported and unsupported Pt-W based catalysts in terms of their catalytic performances (activity, selectivity and durability) and reaction mechanism, aiming for providing an in-depth understanding of this industrially important reaction and a guide to the design of highly active, selective and stable catalysts.

\section{Catalytic performances}

The catalytic performances of the $\mathrm{Pt}-\mathrm{WO}_{x}$ systems are dependent on a variety of catalysts and operation parameters, including the supports, the loadings of Pt and W, the catalyst preparation and treatment trajectory, the presence or absence of additional promoters, the operation temperature and pressure, the reactor type (batch or flow type) and the concentration of feedstock glycerol. These variants make it difficult to rationally compare the performances of different catalysts although in some literatures the turnover frequency (TOF) regarding the formation of 1,3-PDO was provided [19]. Table 2 gives a summary of the performances in terms of glycerol conversion and 1,3-PDO selectivity over various $\mathrm{Pt}^{-\mathrm{WO}_{x}}$ catalyst systems under the specified reaction conditions. It should be noted that the conversion and selectivity are interdependent and often show a seesaw relationship due to the consecutive reactions in Fig. 1. For providing more detailed information

Table 1

Comparison between Ir-Re and Pt-W based catalysts.

\begin{tabular}{lcc}
\hline & $\mathrm{Ir}-\mathrm{Re}$ & $\mathrm{Pt}-\mathrm{W}$ \\
\hline Structure & $3 \mathrm{D} \mathrm{ReO} \mathrm{O}_{x}$ on Ir & Pt on $2 \mathrm{D} \mathrm{WO} \mathrm{O}_{x}$ \\
Ir/Re or Pt/W ratio & $\sim 1$ & $1 / 4-1 / 2$ \\
Reaction temperature & $120^{\circ} \mathrm{C}$ & $160-180^{\circ} \mathrm{C}$ \\
Hydrogen pressure & $8 \mathrm{MPa}$ & $3-5 \mathrm{MPa}$ \\
Additive & $\mathrm{H}^{+}$ & None \\
\hline
\end{tabular}


Table 2

Pt-W based catalysts for hydrogenolysis of glycerol to 1,3-PDO.

\begin{tabular}{|c|c|c|c|c|c|c|c|}
\hline Catalyst & $T\left({ }^{\circ} \mathrm{C}\right)$ & $\mathrm{H}_{2}(\mathrm{MPa})$ & Solvent & Process & $C(\%)$ & $S(\%)$ & Ref. \\
\hline $\mathrm{Rh}(\mathrm{CO})_{2}(\mathrm{acac})+\mathrm{H}_{2} \mathrm{WO}_{4}$ & 200 & 32 (syngas) & $\mathrm{MPI}^{\mathrm{a}}$ & Liquid & 48.0 & 44.0 & [20] \\
\hline $\mathrm{Rh} / \mathrm{C}+\mathrm{H}_{2} \mathrm{WO}_{4}$ & 180 & 8.0 & Sulfone & Liquid & 32.0 & 12.0 & {$[21]$} \\
\hline $\mathrm{Pt} / \mathrm{Al}_{2} \mathrm{O}_{3}+\mathrm{HSiW}^{\mathrm{b}}$ & 200 & 4.0 & $\mathrm{H}_{2} \mathrm{O}$ & Liquid & 49.0 & 28.0 & [22] \\
\hline $\mathrm{Cu}-\mathrm{HSiW} / \mathrm{SiO}_{2}$ & 210 & 0.54 & - & Vapor & 83.4 & 32.1 & [23] \\
\hline $\mathrm{Pt}-\mathrm{HSiW} / \mathrm{SiO}_{2}$ & 200 & 6 & $\mathrm{H}_{2} \mathrm{O}$ & Liquid & 81.2 & 38.7 & [24] \\
\hline $\mathrm{Pt}-\mathrm{HSiW} / \mathrm{ZrO}_{2}$ & 160 & 5 & $\mathrm{H}_{2} \mathrm{O}$ & Liquid & 58.0 & 44.0 & [25] \\
\hline Pt-LiSiW $/ \mathrm{ZrO}_{2}$ & 180 & 5 & $\mathrm{H}_{2} \mathrm{O}$ & Liquid & 43.5 & 53.6 & [26] \\
\hline $\mathrm{PtNps}-\mathrm{HSiW} / \mathrm{mAl}_{2} \mathrm{O}_{3}$ & 200 & 4 & $\mathrm{H}_{2} \mathrm{O}$ & Liquid & 60.5 & 33.3 & [27] \\
\hline $\mathrm{Pt} / \mathrm{WO}_{3} / \mathrm{ZrO}_{2}$ & 170 & 8 & DMI & Liquid & 85.8 & 28.2 & [16] \\
\hline $\mathrm{Pt} / \mathrm{WO}_{3} / \mathrm{ZrO}_{2}$ & 130 & 4 & $\mathrm{H}_{2} \mathrm{O}$ & Liquid & 70.2 & 45.6 & [28] \\
\hline $\mathrm{Pt} / \mathrm{WO}_{3} / \mathrm{ZrO}_{2}$ & 170 & 8 & $\mathrm{DMI}-\mathrm{H}_{2} \mathrm{O}^{\mathrm{c}}$ & Liquid & 31.6 & 34.9 & [29] \\
\hline $\mathrm{Pt} / \mathrm{WO}_{3} / \mathrm{TiO}_{2} / \mathrm{SiO}_{2}$ & 180 & 5.5 & $\mathrm{H} 2 \mathrm{O}$ & Liquid & 15.3 & 50.5 & [30] \\
\hline $\mathrm{Pt}-\mathrm{W} / \mathrm{Al}_{2} \mathrm{O}_{3}$ & 160 & 3 & $\mathrm{H}_{2} \mathrm{O}$ & Liquid & 67.0 & 23.0 & [31] \\
\hline $\mathrm{Pt} / \mathrm{WO}_{x} / \mathrm{AlOOH}$ & 180 & 5 & $\mathrm{H}_{2} \mathrm{O}$ & Liquid & 100 & 66 & [17] \\
\hline $\mathrm{Pt} / \mathrm{WO}_{x} / \mathrm{Al}_{2} \mathrm{O}_{3}$ & 180 & 5 & $\mathrm{H}_{2} \mathrm{O}$ & Liquid & 80.4 & 35.3 & [32] \\
\hline $\mathrm{Pt} / \mathrm{WO}_{x} / \mathrm{Al}_{2} \mathrm{O}_{3}$ & 200 & 4.0 & $\mathrm{H}_{2} \mathrm{O}$ & Liquid & 49 & 28 & [33] \\
\hline $\mathrm{PtW} / \mathrm{ZrSi}$ & 180 & 5 & - & Liquid & 54.3 & 52.0 & [34] \\
\hline $\mathrm{Pt} / \mathrm{WO}_{x} / \mathrm{Al}_{2} \mathrm{O}_{3}$ & 200 & 4.5 & $\mathrm{H}_{2} \mathrm{O}$ & Liquid & 53.1 & 51.9 & [35] \\
\hline $\mathrm{Pt}-\mathrm{WO}_{x} / \mathrm{Al}_{2} \mathrm{O}_{3}$ & 160 & 5 & - & Liquid & 64.2 & 66.1 & [36] \\
\hline $\mathrm{Pt}-\mathrm{Li}_{2} \mathrm{~B}_{4} \mathrm{O}_{7} / \mathrm{WO}_{x} / \mathrm{ZrO}_{2}$ & 150 & 4 & $\mathrm{H}_{2} \mathrm{O}$ & Liquid & 90.7 & 36 & [37] \\
\hline $\mathrm{Pt} / \mathrm{WO}_{3} / \mathrm{ZrO}_{2}$ & 140 & 8 & $\mathrm{H}_{2} \mathrm{O}$ & Liquid & 78.3 & 64.8 & [38] \\
\hline $\mathrm{Pt} / \mathrm{ZrW}$ & 180 & 8 & $\mathrm{H}_{2} \mathrm{O}$ & Liquid & 53.4 & 36 & [39] \\
\hline $\mathrm{Pt} / \mathrm{WO}_{3} / \mathrm{Al}_{2} \mathrm{O}_{3}$ & 260 & 0.1 & - & Vapor & 99 & 14 & [40] \\
\hline Pt/WAlSi & 160 & 6 & $\mathrm{H}_{2} \mathrm{O}$ & Liquid & 48 & 56 & [41] \\
\hline $\mathrm{Pt}^{-W O}{ }_{x} / \mathrm{SAPO}-34$ & 210 & 6 & $\mathrm{H}_{2} \mathrm{O}$ & Liquid & 44.3 & 19.2 & [42] \\
\hline Pt/W-SBA-15 & 150 & 4 & $\mathrm{H}_{2} \mathrm{O}$ & Liquid & 86.8 & 70.8 & [43] \\
\hline $\mathrm{Pt} / m-\mathrm{WO}_{3}$ & 180 & 5.5 & $\mathrm{H}_{2} \mathrm{O}$ & Liquid & 18.0 & 39.3 & [44] \\
\hline Pt/TiW & 180 & 5.5 & $\mathrm{H}_{2} \mathrm{O}$ & Liquid & 24.2 & 33.5 & [45] \\
\hline $\mathrm{Pt} / \mathrm{WO}_{x}$ & 140 & 1 & $\mathrm{H}_{2} \mathrm{O}$ & Liquid & 37.4 & 35.1 & [19] \\
\hline $\mathrm{AuPt} / \mathrm{WO}_{x}$ & 140 & 1 & $\mathrm{H}_{2} \mathrm{O}$ & Liquid & 52.0 & 56.3 & [18] \\
\hline $\mathrm{Pt} / \mathrm{Nb}-\mathrm{WO}_{x}$ & 160 & 5 & $\mathrm{H}_{2} \mathrm{O}$ & Liquid & 40.3 & 27.5 & [46] \\
\hline $\mathrm{Pt} / \mathrm{Au} / \mathrm{WO}_{3}$ & 155 & 5 & $\mathrm{H}_{2} \mathrm{O}$ & Liquid & 30.7 & 54.3 & [47] \\
\hline
\end{tabular}

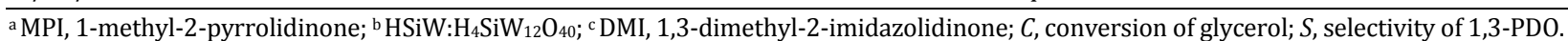

about the catalyst nature and correlating the structure with performance, we classify these catalysts into three types and discuss them separately in the below subsections.

\subsection{Tungstic acid and tungsten heteropolyacids (HPAs)}

The pioneering work of using tungsten in glycerol hydrogenolysis was conducted by Che [20] at Celanese Corporation in 1980s. According to his work, by using $\mathrm{Rh}(\mathrm{CO})_{2}$ (acac) and $\mathrm{H}_{2} \mathrm{WO}_{4}$ homogeneous catalysts in the solvent of 1-methyl-2-pyrrolidinone under synthesis gas $\left(\mathrm{CO} / \mathrm{H}_{2}=1 / 2\right)$ atmosphere at $200{ }^{\circ} \mathrm{C}$, the yields of 1,3-PDO and 1,2-PDO were $21 \%$ and $23 \%$, respectively. Moreover, when $\mathrm{H}_{2} \mathrm{WO}_{4}$ was replaced by other protonic acid, 1,3-PDO and 1,2-PDO were not detected, which is a strong indicator that $\mathrm{H}_{2} \mathrm{WO}_{4}$ plays an important role in hydrogenolysis of glycerol. Meanwhile, the catalytic performance is sensitive to the amount of $\mathrm{H}_{2} \mathrm{WO}_{4}$ : when twice the amount of $\mathrm{H}_{2} \mathrm{WO}_{4}$ was added, the catalytic activity and the product yield decreased by $2 / 3$. In 2004, Chaminand et al. [21] used heterogeneous $\mathrm{Rh} / \mathrm{C}$ to replace homogeneous $\mathrm{Rh}(\mathrm{CO})_{2}$ (acac) for glycerol hydrogenolysis reaction. The result showed that the selectivity ratio of 1,3-PDO/1,2-PDO was 2 in sulfolane solvent at $180^{\circ} \mathrm{C}$, but the 1,3-PDO selectivity was not high (12\%). When the reaction was operated in water, the selectivity ratio of 1,3-PDO/1,2-PDO reversed. In 2011, Dam et al. [22] investigated the effect of various tungsten-based additives, including $\mathrm{H}_{2} \mathrm{WO}_{4}$, phosphotungstic acid $\left(\mathrm{H}_{3} \mathrm{PW}_{12} \mathrm{O}_{40}\right)$ and silicotungstic acid $\left(\mathrm{H}_{4} \mathrm{SiW}_{12} \mathrm{O}_{40}\right)$, on the glycerol hydrogenolysis over commercial catalysts $\left(\mathrm{Pd} / \mathrm{SiO}_{2}, \mathrm{Pd} / \mathrm{Al}_{2} \mathrm{O}_{3}, \mathrm{Pt} / \mathrm{SiO}_{2}\right.$ and $\mathrm{Pt} / \mathrm{Al}_{2} \mathrm{O}_{3}$ ) in water at $200{ }^{\circ} \mathrm{C}$. Among various dual catalysts, $\mathrm{Pt} / \mathrm{Al}_{2} \mathrm{O}_{3}+\mathrm{H}_{4} \mathrm{SiW}_{12} \mathrm{O}_{40}$ (HSiW) showed the best performance with $49 \%$ conversion of glycerol and $28 \%$ selectivity of 1,3-PDO. By contrast, when Pd was used as the active metal, the main product was 1,2-PDO. Although this work has shown a sign of the uniqueness of Pt-W pair in the formation of 1,3-PDO, how they worked synergistically was not clear yet.

Compared with dissolved homogeneous polyoxometalates, supported heterogeneous catalysts should be more favored for practical applications. Zhu et al. [23] prepared $\mathrm{Cu}-\mathrm{H}_{4} \mathrm{SiW}_{12} \mathrm{O}_{40} / \mathrm{SiO}_{2}$ catalyst for vapor-phase glycerol hydrogenolysis. At the optimum conditions $\left(210^{\circ} \mathrm{C}, 0.54 \mathrm{MPa} \mathrm{H}_{2}\right.$ without water), the glycerol conversion and 1,3-PDO selectivity reached $83.4 \%$ and $32.1 \%$, respectively. Later, the same group reported that aqueous phase glycerol hydrogenolysis over 
Pt- $\mathrm{H}_{4} \mathrm{SiW}_{12} \mathrm{O}_{40} / \mathrm{SiO}_{2}$ catalyst [24] with a flow reactor. Under the optimum conditions, glycerol conversion and 1,3-PDO selectivity reached $81.2 \%$ and $38.7 \%$, respectively. IR spectra of adsorbed pyridine showed that the addition of $\mathrm{H}_{4} \mathrm{SiW}_{12} \mathrm{O}_{40}$ increased the acid sites, especially Brønsted acid sites. Control experiments showed that under the same conditions $\mathrm{Cu}-\mathrm{H}_{4} \mathrm{SiW}_{12} \mathrm{O}_{40} / \mathrm{SiO}_{2}$ catalyst gave only $9.1 \%$ glycerol conversion and 8.9\% 1,3-PDO selectivity, again demonstrating the uniqueness of Pt-W pair in favoring the 1,3-PDO formation. In addition to metal type, the support was also found to have profound effect on the activity and selectivity. For example, $\mathrm{Pt}-\mathrm{H}_{4} \mathrm{SiW}_{12} \mathrm{O}_{40} / \mathrm{ZrO}_{2}$ was able to catalyze the reaction at lower temperatures; 44\% 1,3-PDO selectivity and 58\% glycerol conversion were achieved at $160{ }^{\circ} \mathrm{C}$ [25]. The performance of $\mathrm{Pt}-\mathrm{H}_{4} \mathrm{SiW}_{12} \mathrm{O}_{40} / \mathrm{ZrO}_{2}$ was further improved by modification with alkali metals. Alkali metals (Li, $\mathrm{K}, \mathrm{Rb}$ and $\mathrm{Cs}$ ) were doped onto $\mathrm{Pt}-\mathrm{H}_{4} \mathrm{SiW}_{12} \mathrm{O}_{40} / \mathrm{ZrO}_{2}$ by an ion-exchange method using alkali nitrate. The ratio of alkali metal to polyoxometalate was set to 2. Among various alkali-metal promoted systems, $\mathrm{Pt}-\mathrm{Li}_{4} \mathrm{SiW}_{12} \mathrm{O}_{40} / \mathrm{ZrO}_{2}$ [26] showed a higher activity and 1,3-PDO selectivity than unmodified catalyst, attaining $43.5 \%$ glycerol conversion and $53.6 \% 1$ 1,3-PDO selectivity at $180{ }^{\circ} \mathrm{C}$. The introduction of Li cations not only modified the acidity but also improved the tolerance to water solvent. Zhang et al. [27] synthesized a structurally modified PtNps-HSiW $/ \mathrm{mAl}_{2} \mathrm{O}_{3}$ catalyst by assembling platinum nanoparticles (PtNPs) into ordered mesoporous alumina, which could increase the Brønsted acid sites and the dispersion of $\mathrm{Pt}$, and even decrease the loss of $\mathrm{Pt}$ during reuse. This catalyst offered $60.5 \%$ glycerol conversion and $33.3 \% 1,3-\mathrm{PDO}$ selectivity at $200{ }^{\circ} \mathrm{C}$.

In summary, both tungstic acid and tungsten HPAs, when in combination use with supported Pt catalyst, can lead to the selective formation of 1,3-PDO via glycerol hydrogenolysis. In addition to the acidity of HPAs as well as the deposition sequence relative to $\mathrm{Pt}$, one key parameter to affect the efficiency of 1,3-PDO formation should be the ratio of Pt to W, which was, however, overlooked. Moreover, either tungstic acid or tungsten HPAs was difficult to recover and then reuse. Even when the tungsten HPAs were supported on certain oxide support, they also run the risk of being leaching during the hydrothermal reactions. Thereby, more robust $\mathrm{Pt}-\mathrm{W}$ catalysts are required.

\subsection{Supported Pt-WO $\mathrm{O}_{x}$ catalysts}

A wide sort of supported Pt-WO $\mathrm{W}_{x}$ catalysts have been investigated for glycerol hydrogenolysis thanks to their tunable acidity, improved Pt-WO ${ }_{x}$ interaction as well as desirable robustness. In as early as 2008, Kurosaka et al. [16] investigated $\mathrm{Pt} / \mathrm{WO}_{3}$ supported on different oxides including Al-MCM-41, $\mathrm{SiO}_{2}-\mathrm{Al}_{2} \mathrm{O}_{3}, \mathrm{Al}_{2} \mathrm{O}_{3}$, anatase $\mathrm{TiO}_{2}$, $\mathrm{HY}$ zeolite and $\mathrm{ZrO}_{2}$ for glycerol hydrogenolysis in 1,3-dimethyl-2-imidazolidinone (DMI) solvent. Among them, $\mathrm{Pt} / \mathrm{WO}_{3} / \mathrm{ZrO}_{2}$ showed the highest activity, 1,3-PDO/1,2-PDO ratio and 1,3-PDO yield (24.2\%). Nevertheless, due to lack of in-depth characterizations of the catalyst, the reason for the superior performance of $\mathrm{Pt} / \mathrm{WO}_{3} / \mathrm{ZrO}_{2}$ catalyst was not clear. In 2010, Qin et al. [28] reported that
$\mathrm{Pt} / \mathrm{WO}_{3} / \mathrm{ZrO}_{2}$ catalysts were highly active and selective for hydrogenolysis of glycerol in aqueous phase; $70.2 \%$ glycerol conversion and 45.6\% 1,3-PDO selectivity were achieved at $130{ }^{\circ} \mathrm{C}$ and $4 \mathrm{MPa} \mathrm{H}_{2}$ over the catalyst with $3.0 \mathrm{wt} \% \mathrm{Pt}$ and 10 wt $\% \mathrm{~W}$ loadings. The significantly different performances of the above two $\mathrm{Pt} / \mathrm{WO}_{3} / \mathrm{ZrO}_{2}$ catalysts are partially due to the effect of solvent. In fact, Gong et al. [29] compared the performance of $\mathrm{Pt} / \mathrm{WO}_{3} / \mathrm{ZrO}_{2}$ in different solvents, and found that 1,3-PDO selectivity was higher in water than in MDI. More interesting, when 1:1 DMI-water mixture was used as the solvent, the 1,3-PDO yield was almost doubled compared with that in the individual single solvent. Besides the solvent effect, the catalyst preparation method as well as the relative loading of $\mathrm{Pt}$ and $\mathrm{W}$ in the above works is also different, which resulted in different dispersion of $\mathrm{Pt}$ and $\mathrm{W}$ as well as their interfacial structure, and consequently different activity and selectivity. Gonget al. [30] also prepared a series of $\mathrm{Pt} / \mathrm{WO}_{3} / \mathrm{TiO}_{2} / \mathrm{SiO}_{2}$ catalysts with different loadings and employed them to the hydrogenolysis of aqueous glycerol. The dependence of catalytic performance on the loading amount of Ti and W showed a volcano-curve. The optimal loadings of Ti and $\mathrm{W}$ as oxides were $10 \%$ and $5 \%$, respectively, and the glycerol conversion and 1,3-PDO selectivity reached $15.3 \%$ and $50.5 \%$, respectively. The XRD patterns verified one role of $\mathrm{TiO}_{2}$ is to improve the dispersion of Pt. The profiles of temperature-programmed desorption (TPD) of $\mathrm{NH}_{3}$ and IR spectra of adsorbed pyridine showed that the addition of $\mathrm{W}$ enhanced the acidity of the catalyst in terms of both acid amount and strength, especially Brønsted acid sites. All these results have demonstrated that Brønsted acid sites are demanded in the reaction and they are closely related with the $\mathrm{W}$ content.

Compared with $\mathrm{Pt} / \mathrm{WO}_{3} / \mathrm{ZrO}_{2}$, alumina-supported Pt-W catalysts show higher activity and 1,3-PDO selectivity. Suzukiet al. [31] of KAO Corporation first reported that $67 \%$ selectivity to 1,3-PDO was obtained at $23 \%$ glycerol conversion using Pt (5 $\mathrm{wt} \%)-\mathrm{W}(5 \mathrm{wt} \%) / \mathrm{Al}_{2} \mathrm{O}_{3}$ catalyst in their patent in 2007. Then, Kaneda et al. [17] reported that boehmite-supported Pt-W catalyst gave rise to superior activity and selectivity; the glycerol conversion and 1,3-PDO selectivity achieved 100\% and 66\%, respectively, at $180{ }^{\circ} \mathrm{C}$ and $5 \mathrm{MPa} \mathrm{H}_{2}$. This is the best result reported so far. The superior performance was ascribed to the abundant surface Al-OH species on the surface of boehmite, which was, however, not sufficiently supported by the data provided. Recently, Lei et al. [32] studied the glycerol hydrogenolysis over Pt/ $\mathrm{WO}_{x} / \mathrm{Al}_{2} \mathrm{O}_{3}$ catalyst in fixed-bed reactor, and achieved the highest space-time yield of 1,3-PDO (191.7

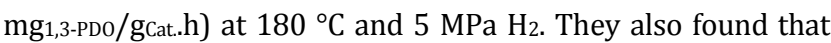
both the glycerol conversion and 1,3-PDO selectivity were highly dependent on Pt and W loadings (Fig. 2) and the appropriate $\mathrm{Pt} / \mathrm{W}$ molar ratio was in the range of $1 / 2-1 / 4$. Based on their studies, at the optimum Pt ( $\sim \mathrm{wt} \%)$ and $\mathrm{W}$ loadings $(10$ $\sim 15 \mathrm{wt} \%), \mathrm{WO}_{x}$ existed as submonolayer polytungstates on the alumina surface and Pt was highly dispersed (dispersion > $50 \%$ ) on the $\mathrm{WO}_{x}$, which promoted the in situ formation of strong Brønsted acid sites through hydrogen dissociation and spillover. As a result, the selective hydrogenolysis of glycerol to 1,3-PDO was favored. 

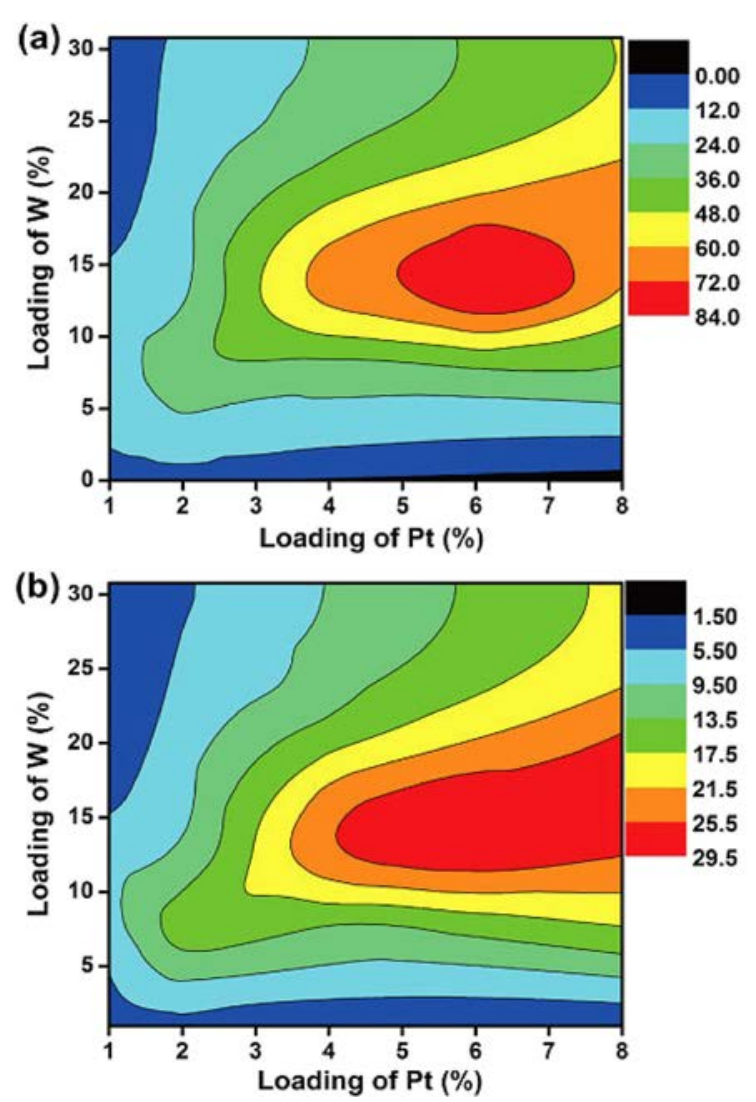

Fig. 2. Contours showing the glycerol conversion (a) and 1,3-PDO yield (b) as functions of W and Pt loadings [32].

In addition to metal oxides supported $\mathrm{Pt} / \mathrm{WO}_{x}$ catalysts $[16,17,28-41], \mathrm{Pt}^{-} \mathrm{WO}_{x}$ supported on zeolites $[42,43]$ were also reported. In particular, when $\mathrm{W}$ was incorporated into SBA-15 by a sol-gel method followed by deposition of $\mathrm{Pt}$, the resulting Pt/W-SBA-15 (W/Si = 1/640) exhibited 1,3-PDO selectivity of $70.8 \%$ even at a high glycerol conversion of $86.8 \%$ [43]. This catalyst is quite different from the other metal oxides supported $\mathrm{Pt}-\mathrm{W}$ systems in that the tungsten in the Pt/W-SBA-15 $(\mathrm{W} / \mathrm{Si}=1 / 640)$ was in the form of isolated $\mathrm{WO}_{4}$ rather than submonolayer polytungstates. While the authors assumed that the hydride $\mathrm{WO}_{4}$ was the active center, more characterization data are required to explain the superior performance of the Pt/W-SBA-15 catalysts.

\subsection{Mesoporous $W_{x}$ supported Pt catalysts}

In order to study the interaction between $\mathrm{Pt}$ and $\mathrm{WO}_{x}$ without interference of a third oxide support, Wang and coworkers developed mesoporous $\mathrm{WO}_{x}$-supported $\mathrm{Pt}$ and Pt-Au bimetallic catalysts $[18,19,44-47]$. The mesoporous $\mathrm{WO}_{x}$ was featured with large surface area $\left(126 \mathrm{~m}^{2} / \mathrm{g}\right)$ and abundant oxygen vacancies $(x=2.8)$, which favored the dispersion of Pt as pseudo-single atoms. Such super-high dispersion of Pt gave rise to moderate glycerol conversion (37.4\%) and 1,3-PDO selectivity (35.1\%) even at relatively low temperature and pressure (413 $\mathrm{K}, 1 \mathrm{MPa} \mathrm{H}_{2}$ ) [19]. When a minor amount of Au was incorporated, the resulting $\mathrm{Au}-\mathrm{Pt} / \mathrm{WO}_{x}$ provided greatly enhanced glycerol conversion (52.0\%) and 1,3-PDO selectivity (56.3\%) under identical conditions [18]. Characterization results revealed that the incorporation of $\mathrm{Au}$ facilitated the reduction of $\mathrm{WO}_{x}$ and increased the in situ Brønsted acid sites, thus leading to improved activity and selectivity.

\section{Reaction mechanism}

There are two main mechanisms that have been proposed for the glycerol hydrogenolysis: dehydration-hydrogenation [48] and direct hydrogenolysis [11]. As shown in Fig. 3(a), the dehydration-hydrogenation route involves acid-catalyzed dehydration of glycerol and the subsequent hydrogenation of intermediate in the presence of metallic sites to obtain the final product. In this mechanism, there are two possible intermediates: acetol and 3-hydroxypropanal (3-HPA) which can be further hydrogenated to 1,2-PDO and 1,3-PDO, respectively. Since the secondary carbocation is more stable than the primary one, 3-HPA should be kinetically favored. However, due to the thermodynamically unstable nature of 3-HPA, it must be quickly hydrogenated upon formation, otherwise it will undergo the further dehydration to more stable acrolein leading to the formation of 1-PO. On the other hand, acetol is thermodynamically stable and therefore was experimentally observed under certain conditions (e.g., reduced $\mathrm{H}_{2}$ pressure) [48]. Zhu et al. [36] investigated the product selectivity as a function of acid sites over $\mathrm{Pt} / \mathrm{Al}_{2} \mathrm{O}_{3}$ and $\mathrm{Pt}-\mathrm{WO}_{x} / \mathrm{Al}_{2} \mathrm{O}_{3}$, and found that the 1,2-PDO yield correlated well with the Lewis acid sites while the 1,3-PDO yield correlated well with the Brønsted acid sites. Similarly, García-Fernández et al. [35] found that the maximum 1,3-PDO selectivity was reached as the largest B/L ratio, which also suggested that the Brønsted acid sites are required for the formation of 1,3-PDO. While the dehydration-hydrogenation mechanism can explain the formation of 1,2-PDO, it is difficult to rationalize the indispensable role of $\mathrm{WO}_{x}$ in the formation of 1,3-PDO. Moreover, when the reaction was performed in $\mathrm{N}_{2}$, glycerol was barely converted at all, let alone observing the key intermediate 3-HPA although the $\mathrm{Pt} / \mathrm{WO}_{x} /$ support catalyst contains both Lewis and Brønsted acid sites. In this case, alternative reaction mechanism needs to be developed.

Direct hydrogenolysis mechanism was first proposed by Tomishige and coworkers [11] over the $\mathrm{Ir}-\mathrm{ReO}_{x} / \mathrm{SiO}_{2}$ catalyst, where glycerol is first adsorbed on $\mathrm{ReO}_{x}$ surface to form terminal alkoxide, and then the hydride activated on the Ir metal attacks the 2-position of the alkoxide to cleave the secondary $\mathrm{C}-\mathrm{O}$ bond (Fig. 3(b)). Because 6-membered-ring transition state is more stable than 7-membered-ring transition state, the cleavage of secondary $\mathrm{C}-\mathrm{O}$ bond is favored over the primary $\mathrm{C}-\mathrm{O}$ bond. In comparison with the dehydration-hydrogenation mechanism, the direct hydrogenolysis mechanism combines the oxophilic nature of $\mathrm{Re}$ and the interface with Ir (Re-Ir bonding), and appears more plausible although the 6-membered-ring transitional structure is difficult to detect by experiment.

Different from the above mechanism over the $\mathrm{Ir}-\mathrm{ReO}_{x} / \mathrm{SiO}_{2}$, the formation of 1,3-PDO over Pt-WO $\mathrm{W}_{x}$ system was proposed to follow a proton-involved direct hydrogenolysis mechanism (Fig. 3(c)), instead of hydride-involved one. One supporting 


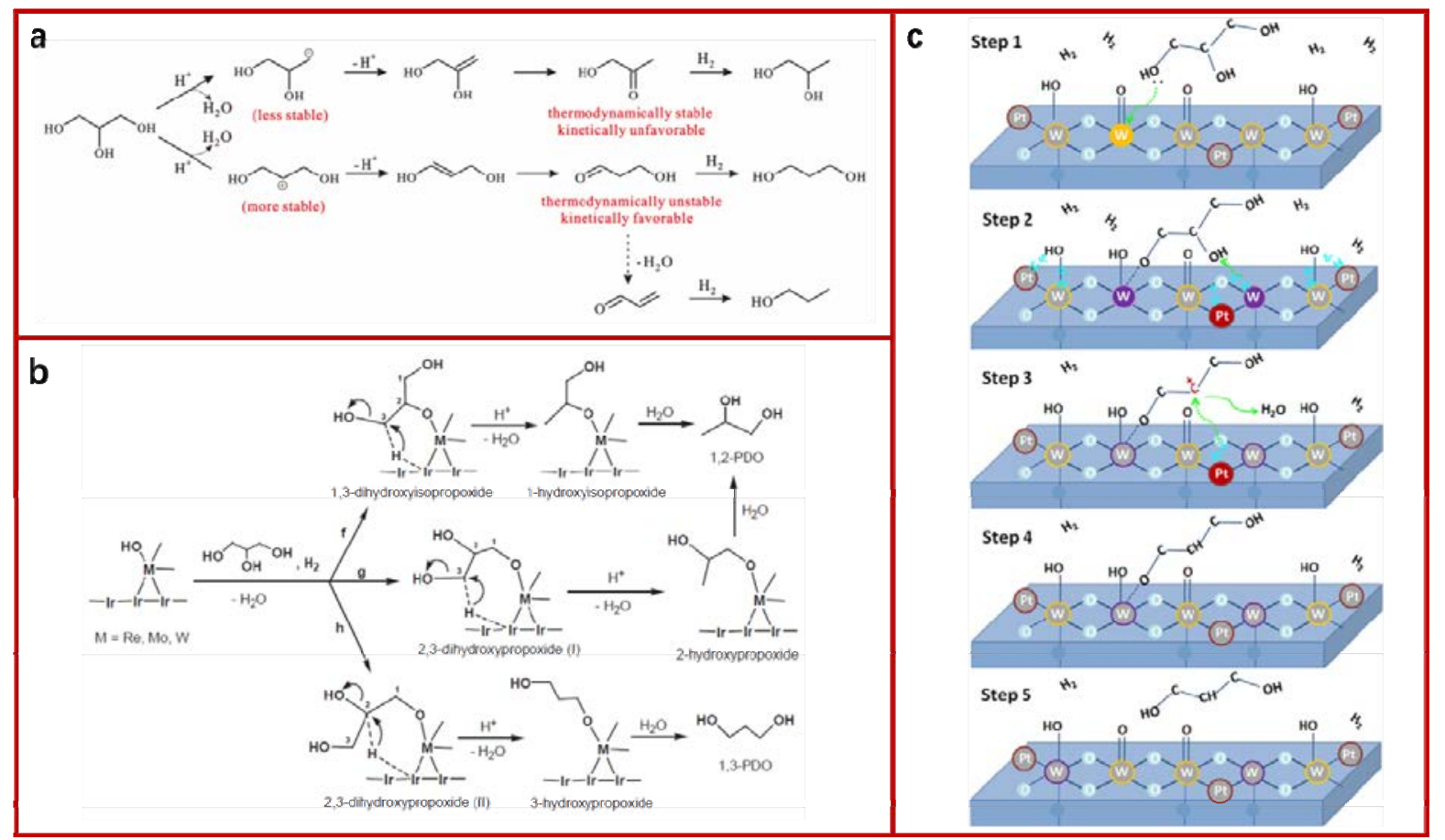

Fig. 3. Reaction mechanisms for glycerol hydrogenolysis. (a) Dehydration-hydrogenation mechanism [48]; (b) hydride-involved direct hydrogenolysis mechanism [11]; (c) proton-involved direct hydrogenolysis mechanism [19].

evidence for this mechanism is the observation of in situ formed Brønsted acid sites by dissociation of $\mathrm{H}_{2}$ at Pt surface and then spillover to the $\mathrm{WO}_{x}$. Ma and coworkers investigated the correlation between $\mathrm{H}$ spillover and glycerol conversion over $\mathrm{Pt} / \mathrm{WO}_{3} / \mathrm{ZrO}_{2}$ catalyst [39], and obtained a nearly linear relationship (Fig. 4(a)). In line with this result, Wang and coworkers also observed a positive relationship of $\mathrm{H}$ spillover with the 1,3-PDO yield on the best-performance catalyst $2 \mathrm{Pt} / 7.5 \mathrm{~W} / \mathrm{Al}_{2} \mathrm{O}_{3}$ [32]. Moreover, they used dehydration/dehydrogenation of 2-butanol as the probe reaction to investigate the in situ generated Brønsted acid sites under $\mathrm{H}_{2}$. As shown in Fig. 4(b), while the dehydrogenation dominates under $\mathrm{N}_{2}$, the reaction switches to the dehydration in $\mathrm{H}_{2}$, indicating that the Brønsted acid sites are generated by $\mathrm{H}_{2}$ dissociation on Pt and spillover to the neighboring $\mathrm{WO}_{x}$. The similar conclusion has also been drawn by other groups on $\mathrm{Pt} / \mathrm{WO}_{3} / \mathrm{ZrO}_{2}$ [38] and Pt/W-SBA-15 [43] catalyst systems.

\section{Catalyst stability}

The promising activity and selectivity of Pt-W based catalysts have attracted a great deal of attention from industry. For practical applications, catalyst stability under long-term running and being exposed to impurities in glycerol is of at least equivalent importance to activity/selectivity. Unfortunately, this issue has rarely been concerned in the reported literatures. Recently, Lei et al. [49] investigated the stability of $\mathrm{Pt} / \mathrm{WO}_{x} / \mathrm{Al}_{2} \mathrm{O}_{3}$ catalyst under an industry-relevant condition of $50 \%$ aqueous glycerol, LHSV of $1 \mathrm{~h}^{-1}$, GHSV of $1000 \mathrm{~h}^{-1}, 180^{\circ} \mathrm{C}$, and $5 \mathrm{MPa} \mathrm{H}_{2}$. A three-stage deactivation (Fig. 5) curve was observed and the fastest deactivation occurred at the initial
$100 \mathrm{~h}$. Characterization results revealed that the deactivation was mainly caused by the aggregation of Pt particles, which significantly decreased the number of accessible Pt sites (the Pt dispersion was reduced from $29.1 \%$ to $10.1 \%$ ) and consequently the number of in situ formed Brønsted acid sites. Therefore, in order to meet the requirement of practical applications, a great deal of efforts should be devoted to the improvement of catalyst durability. To this end, clarification of the deactivation mechanism at the molecular scale is necessary.

\section{Conclusions and perspectives}

The selective hydrogenolysis of glycerol to 1,3-PDO is of highly importance to both fundamental research and practical applications, yet rather challenging due to a spectrum of competitive side reactions. So far, Pt-W bifunctional catalysts have been proved effective for this reaction and various supported and unsupported Pt-W based catalysts have been developed. Among them, $\mathrm{Pt} / \mathrm{WO}_{x} / \mathrm{Al}_{2} \mathrm{O}_{3}$ has shown the most promising activity and selectivity, yet its long-term stability needs to be improved.

The reaction mechanism for the glycerol hydrogenolysis over Pt-W based catalysts is still in debate although three possible reaction mechanisms have been proposed. One key question in addressing the mechanism is the origin of Brønsted acid $[32,39]$. Some studies correlate the 1,3-PDO yield with the permanent Brønsted acid sites on the supported $\mathrm{WO}_{x}$ surface, while others believe that the transient Brønsted acid sites which are formed by hydrogen dissociation and spillover at the Pt-WO $\mathrm{W}_{x}$ interface are responsible for the 1,3-PDO production. More spectroscopy evidences, in particular under working 


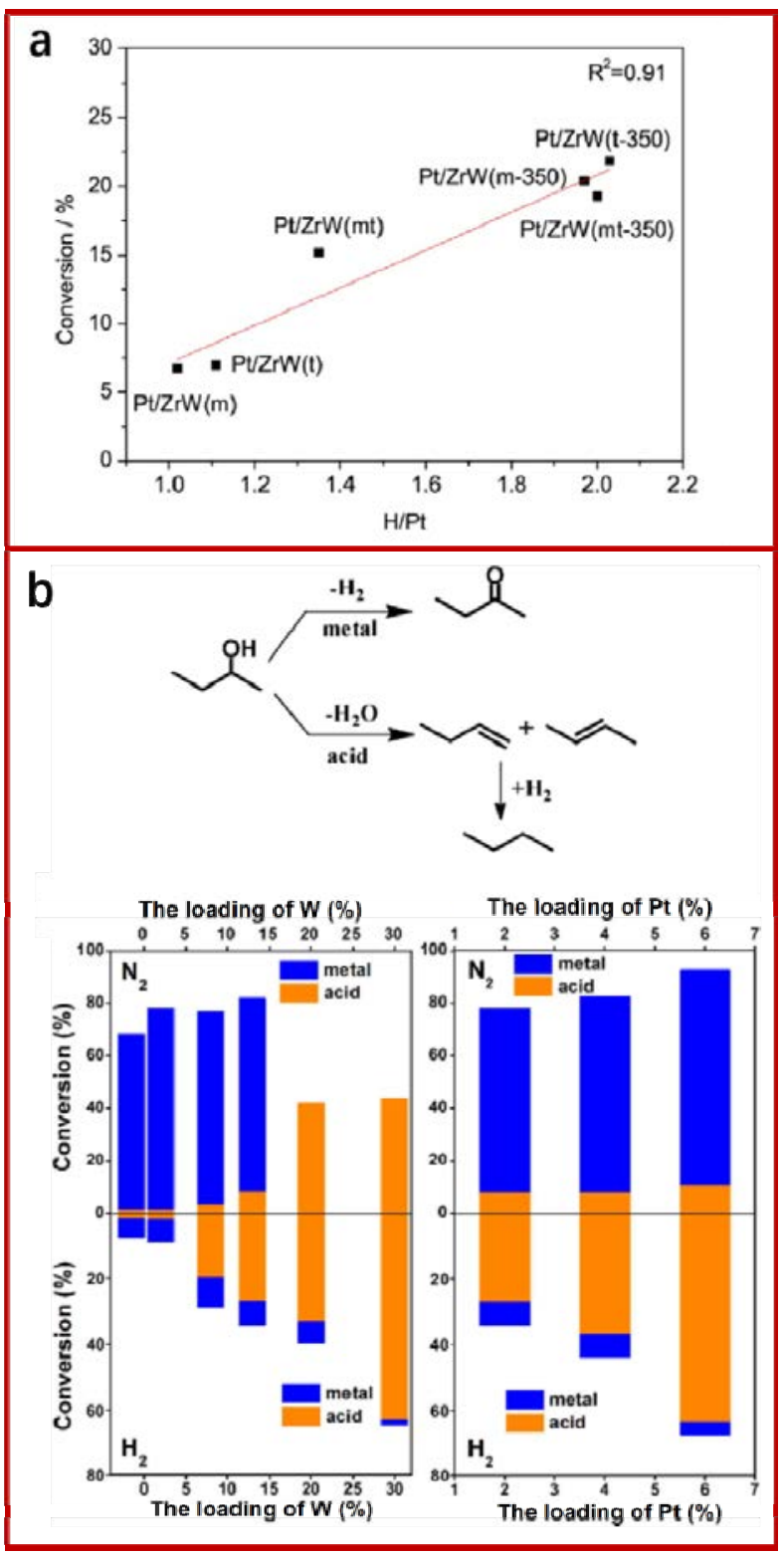

Fig. 4. (a) Linear relationship between $\mathrm{H}$ spillover and glycerol conversion over $\mathrm{Pt} / \mathrm{WO}_{3} / \mathrm{ZrO}_{2}$ catalyst [39]; (b) Measurement of the in situ formed Brønsted acid sites by the probe reaction of dehydration/dehydrogenation of 2-butanol [32].

conditions, are required to address this key question.

There are several key factors affecting the catalytic performances of Pt-W based catalysts. (1) Domain size of $\mathrm{WO}_{x}$. A lot of researches have shown that medium-sized $\mathrm{WO}_{x}$ dispersed as sub-monolayer on the underlying substrate is favorable for the dispersion of Pt and the generation of strong Brønsted acid, both of which are required for the cleavage of the secondary C-O bond of glycerol. (2) Dispersion of Pt. The reaction is rather sensitive to the dispersion of Pt as it relates to the rates of hydrogen dissociation and hydrogenation of unsaturated intermediate. (3) Interaction between $\mathrm{Pt}$ and $\mathrm{WO}_{x}$. Since the reaction occurs probably at the interfacial sites between $\mathrm{Pt}$ and $\mathrm{WO}_{x}$ and strong metal support interaction (SMSI) tends to take place in this system upon reduction at higher temperature, the ex-

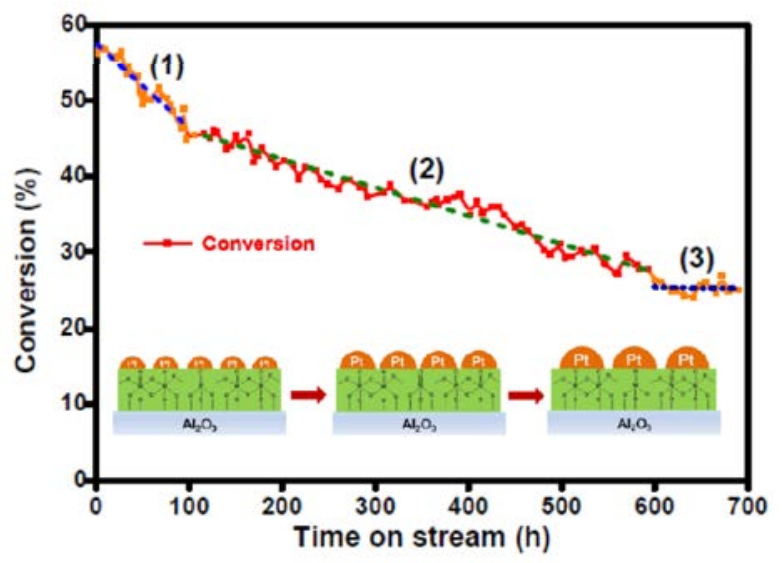

Fig. 5. Stability test of Pt/ $\mathrm{WO}_{3} / \mathrm{Al}_{2} \mathrm{O}_{3}$ catalyst for glycerol hydrogenolysis. The deactivation curve can be fitted with three-stage lines, and the inset is to demonstrate the growing of Pt NPs during each stage of deactivation [49].

quisite control of $\mathrm{Pt}-\mathrm{WO}_{x}$ interaction is of paramount importance to the hydrogen spillover and the in situ formation of Brønsted acid. By innovating the synthesis methods and optimizing the pre-treatment and reaction conditions, the three key structure parameters can be regulated such that they are the most favorable to the formation of 1,3-PDO. There is still a large space to be explored in this direction.

\section{References}

[1] R. A. Sheldon, Green Chem., 2014, 16, 950-963.

[2] A. V. Bridgwater, Biomass and Bioenergy, 2011, 1-27.

[3] A. Behr, J. Eilting, K. Irawadi, J. Leschinski, F. Lindner, Green Chem., 2008, 10, 13-30

[4] S. S. Yazdani, R. Gonzalez, Curr. Opin. Biotechnol, 2007, 18, 213-219.

[5] Y. Nakagawa, M. Tamura, K. Tomishige. J. Mater. Chem. A, 2014, 2, 6688-6702.

[6] M. R. Nimlos, S. J. Blanksby, X. Qian, M. E. Himmel, D. K. Johnson, J. Phys. Chem. A, 2006, 110, 6145-6156.

[7] A. Alhanash, E. F. Kozhevnikova, I. V. Kozhevnikov, Catal. Lett., 2008, 120, 307-311.

[8] M. Balaraju, V. Rekha, P. S. Sai Prasad, R. B. N. Prasad, N. Lingaiah, Catal. Lett., 2008, 126, 119-124.

[9] Y. Nakagawa, Y. Shinmi, S. Koso, K. Tomishige, J. Catal., 2010, 272, 191-194.

[10] Y. Nakagawa, X. Ning, Y. Amada, K. Tomishige, Appl. Catal. A, 2012, 433-434, 128-134.

[11] Y. Amada, Y. Shinmi, S. Koso, T. Kubota, Y. Nakagawa, K. Tomishige, Appl. Catal. B, 2011, 105, 117-127.

[12] S. Koso, H. Watanabe, K. Okumura, Y. Nakagawa, K. Tomishige, Appl. Catal. B, 2012, 111-112, 27-37.

[13] Y. Amada, H. Watanabe, M. Tamura, Y. Nakagawa, K. Okumura, K. Tomishige, J. Phys. Chem. C, 2012, 116, 23503-23514.

[14] M. Tamura, Y. Amada, S. Liu, Z. Yuan, Y. Nakagawa, K. Tomishige, J. Mol. Catal. A, 2014, 388-389, 177-187.

[15] K. Tomishige, Y. Nakagawa, M. Tamura, Green Chem., 2017, 19, 2876-2924.

[16] T. Kurosaka, H. Maruyama, I. Naribayashi, Y. Sasaki, Catal. Commun., 2008, 9, 1360-1363.

[17] R. Arundhathi, T. Mizugaki, T. Mitsudome, K. Jitsukawa, K. Kaneda, 


\section{Graphical Abstract}

Chin. J. Catal., 2020, 41: 1311-1319 doi: 10.1016/S1872-2067(20)63586-0

\section{Selective hydrogenolysis of glycerol to 1,3-propanediol over Pt-W based catalysts}

Jia Wang, Man Yang, Aiqin Wang *

Northwest A\&F University; Dalian Institute of Chemical Physics, Chinese Academy of Sciences

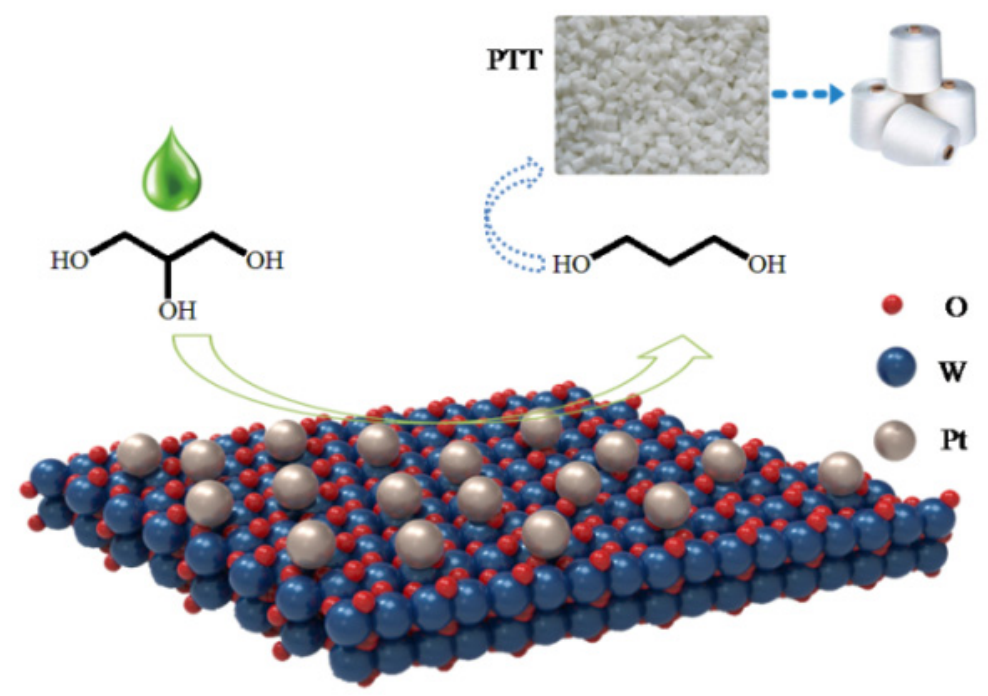

Pt-W based catalysts demonstrate promising performances in the selective hydrogenolysis of glycerol to 1,3-propanediol thanks to the synergy between $\mathrm{Pt}$ and $\mathrm{WO}_{x}$

ChemSusChem., 2013, 6, 1345-1347.

[18] X. Zhao, J. Wang, M. Yang, N. Lei, L. Li, B. Hou, S. Miao, X. Pan, A. Wang, T. Zhang, ChemSusChem, 2017, 10, 819-824.

[19] J. Wang, X. Zhao, N. Lei, L. Li, L. Zhang, S. Xu, S. Miao, X. Pan, A. Wang, T. Zhang, ChemSusChem, 2016, 9, 784-790.

[20] T. M. Che, US Patent 4642 394, 1987.

[21] J. Chaminand, L. A. Djakovitch, P. Gallezot, P. Marion, C. Pinel, C. Rosier, Green Chem., 2004, 6, 359-361.

[22] J. ten Dam, K. Djanashvili, F. Kapteijn, U. Hanefeld, ChemCatChem, 2013, 5, 497-505.

[23] L. Huang, Y. Zhu, H. Zheng, G. Ding, Y. Li, Catal. Lett., 2009, 131, 312-320.

[24] S. Zhu, Y. Zhu, S. Hao, L. Chen, B. Zhang,Y. Li, Catal. Lett., 2012, 142, 267-274.

[25] S. Zhu, Y. Qiu, Y. Zhu, S. Hao, H. Zheng, Y. Li, Catal. Today, 2013, 212, 120-126.

[26] S. Zhu, X. Gao, Y. Zhu, Y. Zhu, X. Xiang, C. Hu, Y. Li, Appl. Catal. B, 2013, 140, 60-67.

[27] M. Gu, Z. Shen, L. Yang, B. Peng, W. Dong, W. Zhang, Ind. Eng. Chem. Res., 2017, 56, 13572-13581.

[28] L. Z. Qin, M. J. Song, C. L. Chen, Green Chem., 2010, 12, 1466-1472.

[29] L. Gong, Y. Lv, Y. Ding, R. Lin, J. Li, W. Dong, T. Wang, W. Chen, Chin. J. Catal., 2009, 30, 1189-1191.

[30] L. Gong, Y. Lu, Y. Ding, R. Lin, J. Li, W. Dong, T. Wang, W. Chen, Appl. Catal. A, 2010, 390, 119-126.

[31] N. Suzuki, M. Takahashi, M. Tamura, JP Patent 2073268 49A,

\section{2}

[32] N. Lei, X. C. Zhao, B. L. Hou, M. Yang, M. X. Zhou, F, Liu, A. Q. Wang, T. Zhang, ChemCatChem, 2019, 11, 3903-3912

[33] J. ten Dam, K. Djanashvili, F. Kapteijn, U. Hanefeld, ChemCatChem, 2013, 5, 497-505.

[34] S. Zhu, X. Gao, Y. Zhu, J. Cui, H. Zheng, Y. Li. Appl. Catal. B, 2014, 158-159, 391-399.

[35] S. García-Fernández, I. Gandarias, J. Requies, M. B. Güemez, S. Bennici, A. Auroux, P. L. Arias, J. Catal., 2015, 323, 65-75.

[36] S. Zhu, X. Gao, Y. Zhu, Y. Li, J. Mol. Catal. A, 2015, 398, 391-398

[37] M. Zhu, C. Chen, React. Kinet. Mech. Catal., 2018, 124, 683-699.

[38] Y. Fan, S. Cheng, H. Wang, J. Tian, S. Xie, Y. Pei, M. Qiao, B. Zong, Appl. Catal. B, 2017, 217, 331-341.

[39] W. Zhou, Y. Zhao, Y. Wang, S. Wang, X. Ma, ChemCatChem, 2016, 8, 3663-3671.

[40] M. Edake, M. Dalil, M. J. D. Mahboub, J. L. Dubois, G. S. Patiencea, RSC Adv., 2017, 7, 3853-3860.

[41] S. Feng, B. Zhao, L. Liu, J. Dong. Ind. Eng. Chem. Res., 2017, 56, 11065-11074.

[42] G. Shi, J. Xu, Z. Song, Z. Cao, K. Jin, S. Xu, Mol. Catal., 2018, 456, $22-30$.

[43] Y. Fan, S. Cheng, H. Wang, D. Ye, S. Xie, Y. Pei, H. Hu, W. Hua, Z. Li, M. Qiao, B. Zong, Green Chem., 2017, 19, 2174-2183.

[44] L. Liu, Y. Zhang, A. Wang, T. Zhang, Chin. J. Catal., 2012, 33, $1257-1261$.

[45] Y. Zhang, X. Zhao, Y. Wang, L. Zhou, J. Zhang, J. Wang, A. Wang, T. 
Zhang, J. Mater. Chem. A, 2013, 1, 3724-3732.

[46] M. Yang, X. Zhao, Y. Ren, J. Wang, N Lei, A. Wang, T. Zhang. Chin. J. Catal., 2018, 39, 1027-1037.

[47] C. Yang, F. Zhang, N. Lei, M. Yang, F. Liu, Z. Miao, Y. Sun, X. Zhao, A.
Wang, Chin. J. Catal., 2018, 39, 1366-1372.

[48] Y. Nakagawa, K. Tomishige, Catal. Sci. Technol., 2011, 1, 179-190.

[49] N. Lei, Z. Miao, F. Liu, H. Wang a, X. Pan, A. Wang, T. Zhang, Chin. J. Catal., 2020, 40, DOI:10.1016/S1872-2067(20)63549-5.

\title{
Pt-W催化剂上甘油选择性氢解制备1,3-丙二醇研究进展
}

\author{
王 佳 ${ }^{\mathrm{a}, \dagger}$, 杨 曼 ${ }^{\mathrm{b}, \mathrm{d}, \dagger}$, 王爱琴 ${ }^{\mathrm{b}, \mathrm{c}, *}$ \\ a西北农林大学林学院, 陕西杨凌 712100 \\ ${ }^{b}$ 中国科学院大连化学物理研究所, 航天催化材料重点实验室, 辽宁大连 116023 \\ c中国科学院大连化学物理研究所, 催化基础国家重点实验室, 辽宁大连 116023 \\ d中国科学院大学, 北京100049
}

摘要: 生物柴油产业迅猛发展导致甘油大量过剩; 另一方面, 1,3-丙二醇在聚酯工业中有着重要应用. 因此, 甘油氢解反应 制1,3-丙二醇反应具有重要的应用价值. 但是由于热力学和空间位阻的限制, 该反应仍存在很大的挑战. 目前, 用于该过程 的催化体系主要包括铱-铼催化体系和铂-铇催化体系两类. 本文重点介绍了Pt-W体系在甘油氢解制备1,3-丙二醇的研究 进展.

首先比较了铇酸和杂多酸/杂多酸盐、负载型 $\mathrm{Pt}-\mathrm{W}$ 和 $\mathrm{Pt} /$ 介孔铇等三类催化剂体系反应性能及其构效关系, 总结了影响 Pt-W催化剂性能的几因素: (1) $\mathrm{WO}_{x}$ 的分散状态: 亚单层分散的中等尺寸的 $\mathrm{WO}_{x}$ 有利于Pt的分散和产生更多的B酸位, 从而 有利于甘油仲羟基的断裂生成1,3-丙二醇. (2) Pt的分散度: $\mathrm{H}_{2}$ 的解离速率和对不饱和中间物种的加氢与Pt的分散度呈现 密切的关系. (3) Pt-WO 间的强相互作用: 有利于氢溢流和原位B酸的形成. 所以, 通过优化合成方法、预处理方法、反应 条件等来调变这三种因素, 以获得高选择性、高活性和稳定性的新型Pt-W催化体系, 是未来应着力探索的方向之一.

此外总结了目前存在的三种基于Pt-W体系的催化剂机理, 其中一些研究者认为, B酸主要来源于 $\mathrm{WO}_{x}$ 表面的本征酸位, 而另一些人则认为源自 $\mathrm{Pt}-\mathrm{WO}_{x}$ 界面原位 $\mathrm{H}_{2}$ 的异裂, 且是Pt-W基催化剂表现出较高1,3-丙二醇选择性的真正原因. 因此, 能 直观检测中间产物的原位表征技术的发展与应用乃是解决这一争议的未来方向. 为了满足实际应用的需要, 应从分子尺 度上理解失活机制, 从而大力提高催化剂的耐久性.

综上, 希望本文能够为甘油选择性氢解制1,3-丙二醇高效催化剂的开发提供有用的信息.

关键词: 甘油; 氢解; 1,3-丙二醇; 铂-氧化铇基催化剂

收稿日期: 2020-02-21. 接受日期: 2020-03-16. 出版日期: 2020-09-05.

*通讯联系人. 电话: (0411)84379348; 传真: (0411)84685940; 电子信箱: aqwang@dicp.ac.cn

†共同第一作者.

基金来源: 国家自然科学基金(21706215, 21690084, 21673228); 陕西省自然科学基金(2018JQ2034); 中央高校基本科研业务费专 项资金(Z109021701).

本文的电子版全文由Elsevier出版社在ScienceDirect上出版(http://www.sciencedirect.com/science/journal/18722067). 